\title{
An assessment of red cell deformability using a simple filtration method
}

\author{
MM DRUMMOND, GDO LOWE, JJF BELCH, JC BARBENEL, AND \\ CD FORBES
}

From the University Department of Medicine, Royal Infirmary, Glasgow G4 OSF, and the Bioengineering Unit, Strathclyde University, Glasgow, UK

SUMMARY We assessed the simple method of measuring red cell deformability described by Reid et al. The technique was found to be reproducible. The validity of the method as a measure of red cell deformation was confirmed by (a) marked reduction of the deformability index after fixation of red cells with glutaraldehyde, and $(b)$ an inverse correlation of deformability index with high-shear blood viscosity $(r=0.4 ; \mathrm{P}<0.001)$. There was no correlation of deformability index with low-shear blood viscosity, plasma viscosity, fibrinogen, or the white cell count. In normal subjects, deformability index was similar in males and females, and in smokers and non-smokers. Patients with acute myocardial infarction, or intermittent claudication, had reduced deformability compared to controls $(P<0.01)$.

Since it was first shown that red blood cells are deformed during their passage through capillaries, many methods for the measurement of red cell deformability have been described. There is, however, a need for a rapid, simple, and reproducible method of measuring red cell deformability suitable for large clinical studies. Reid et al. ${ }^{1}$ described such a simple method, recording the filtration time taken for $1 \mathrm{ml}$ whole blood to pass through $5 \mu$ polycarbonate filters under negative pressure, with correction for haematocrit. We have assessed the reproducibility of this method and investigated its relationship to changes in red cell deformability produced by glutaraldehyde fixation of red cells, or by deforming whole blood at high shear rates in a rotational viscometer. In view of the reported association between plasma fibrinogen and red cell deformability, as measured by a centrifuge method, ${ }^{2}$ we compared deformability with fibrinogen levels and with blood viscosity at low shear rates, which is highly correlated with red cell aggregation by fibrinogen. ${ }^{3}$ As white blood cells may be trapped in the filter pores, and as plasma viscosity may also affect the passage of red cells through the filter, we also correlated deformability with the white cell count and with plasma viscosity. We investigated the effect of sex and smoking habit on red cell deformability in a normal population and measured

Received for publication 31 October 1979 red cell deformability in patients with acute myocardial infarction and in patients with chronic peripheral arterial disease.

\section{Methods}

Venous blood was anticoagulated with EDTA $(1 \mathrm{mg} / \mathrm{ml})$ for measurement of red cell deformability, haematocrit, blood viscosity, plasma viscosity, and white cell count.

\section{RED CELL DEFORMABILITY}

A detailed account of the basic method has already been published. ${ }^{1}$ The method was modified by filling the syringe beyond the $1 \mathrm{ml}$ mark before applying negative pressure, and thus a constant speed was obtained before timing started. This improved reproducibility. The time taken for $1 \mathrm{ml}$ of blood to flow was recorded, from which the volume of blood filtered per minute was calculated. Multiplication of this value by the haematocrit value gave the volume or icd cells filtered per minute (red cell deformability index; RCD). The filters were supplied by Nucleopore, and as a large variation was found between batches, the same batch number was used throughout.

\section{FIBRINOGEN LEVELS}

These were measured in citrated plasma by a thrombin-time method, using a Dade Fibrometer and standards. ${ }^{4}$ 
HAEMATOCRIT

Haematocrit measurements were made with a microhaematocrit centrifuge (Hawksley), spinning at $13000 \mathrm{~g}$ for 5 minutes. Plasma viscosity was measured at $37^{\circ} \mathrm{C}$ in a BS-M3 capillary viscometer. Blood viscosity was measured at $37^{\circ} \mathrm{C}$ in a Contraves LS-30 rotational viscometer at a low shear rate $\left(0.94 \mathrm{~s}^{-1}\right)$ and a high shear rate $\left(94.5 \mathrm{~s}^{-1}\right)$. Viscosity was corrected to a standard haematocrit of 0.45 using a regression equation obtained from the population studied. White cell count was measured by Coulter ' $S$ '.

Samples were taken from healthy hospital staff and from patients in medical and surgical wards. Patients with acute myocardial infarction were studied within seven days of onset of an acute transmural infarction with typical history and serial changes in electrocardiograms and serum enzymes. Patients with chronic peripheral arterial disease had a typical history of intermittent claudication and absent foot pulses.

Differences in means of the variables studied were analysed by Student's $t$ test, and correlations were determined by the method of least squares.

\section{Results}

\section{RELATION TO HAEMATOCRIT}

Figure 1 shows the correlation between whole blood filtration rate and haematocrit in 200 subjects. Reconstitution experiments to give haematocrit values in the range $0.30-0.60$ resulted in a significant negative correlation $(r=0.99 \quad P<0.05)$ between

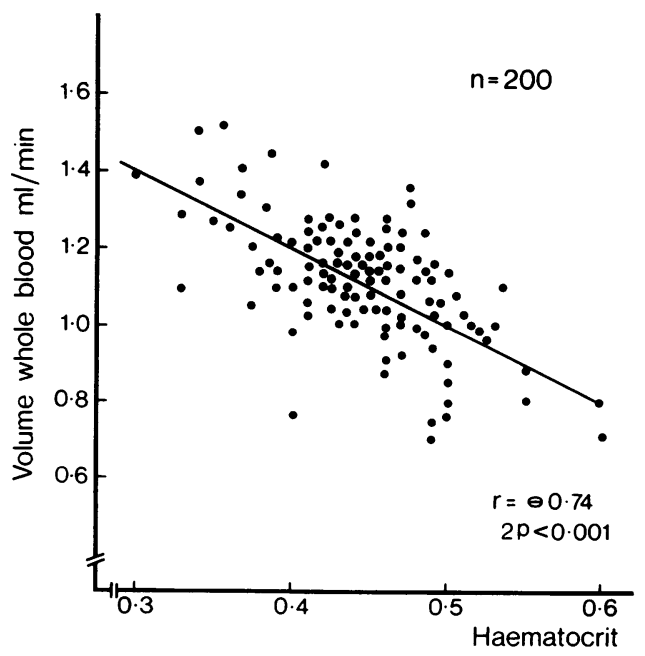

Fig. 1 Correlation between whole blood filtration rate and haematocrit in a population of patients and normals. whole blood filtration rate and haematocrit. Multiplication by the haematocrit to obtain the RCD abolished this correlation $(\mathrm{r}=0.01)$.

\section{REPRODUCIBILITY}

On each of 20 normal samples, seven measurements of RCD were performed; the mean coefficient of variation was found to be $3.7 \%$. We therefore decided to take the mean of triplicate measurements on each sample.

\section{EFFECT OF FIXATION OF RED CELLS BY GLUTARALDEHY DE}

In order to validate the theory that rigid cells would be detected by the method, red cells were treated with $1.5 \%(\mathrm{v} / \mathrm{v})$ glutaraldehyde in phosphate buffered saline at $4^{\circ} \mathrm{C}$ for 48 hnurs, as described by Largo et al..$^{5}$ The volume of red cells was $0.53 \mathrm{ml} / \mathrm{min}$ before glutaraldehyde treatment and $0.008 \mathrm{ml} / \mathrm{min}$ after treatment, indicating that the rigid cells were much less able to pass through the pores in the filter. A control experiment storing cells at $4^{8} \mathrm{C}$ for 48 hours in phosphate buffered saline without glutaraldehyde produced a less marked loss of deformability $(0.50 \mathrm{ml} / \mathrm{min}$ before, and $0.28 \mathrm{ml} / \mathrm{min}$ after, treatment).

\section{CORRELATION WITH HIGH SHEAR BLOOD VISCOSITY}

In a population of 200 normals and patients, RCD was correlated inversely with blood viscosity at the high shear rate of $94.5 \mathrm{~s}^{-1}$, corrected to a standard haematocrit of 0.45 (Fig. 2).

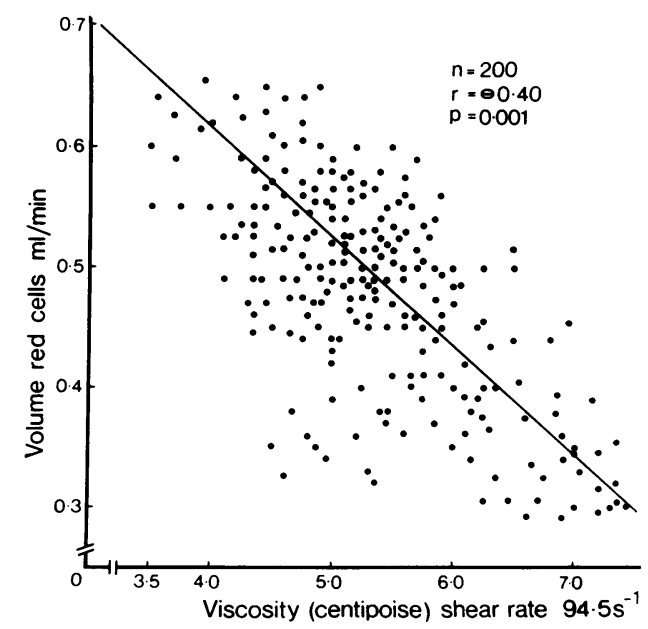

Fig. 2 Correlation of deformability index with high shear blood viscosity. 
Red cell deformability in relation to sex and smoking

\begin{tabular}{|c|c|c|c|}
\hline & Males & Females & Total \\
\hline Non-smokers & $\begin{array}{l}\mathrm{N}=23 \\
\text { Age }=31 \cdot 2 \pm 8 \cdot 1 \\
\mathrm{RCD}=0.49 \pm 0.06\end{array}$ & $\begin{array}{l}N=15 \\
\text { Age }=26.9 \pm 6.4 \\
R C D=0.52 \pm 0.05\end{array}$ & $\begin{array}{l}N=38 \\
\text { Age }=29.5 \pm 7.7 \\
R C D=0.50 \pm 0.06\end{array}$ \\
\hline Smokers & $\begin{array}{l}N=15 \\
\text { Age }=27 \cdot 5 \pm 8 \cdot 5 \\
\operatorname{RCD}=0.48 \pm 0.08\end{array}$ & $\begin{array}{l}N=13 \\
\text { Age }=29.2 \pm 10.2 \\
R C D=0.48 \pm 0.06\end{array}$ & $\begin{array}{l}\mathrm{N}=28 \\
\text { Age }=28 \cdot 3 \pm 9 \cdot 2 \\
\mathrm{RCD}=0.48 \pm 0.07\end{array}$ \\
\hline Total & $\begin{array}{l}N=38 \\
\text { Age }=29 \cdot 3 \pm 8 \cdot 3 \\
R C D=0.48 \pm 0.07\end{array}$ & $\begin{array}{l}\mathrm{N}=28 \\
\mathrm{Age}=28 \cdot 1 \pm 8 \cdot 2 \\
\mathrm{RCD}=0 \cdot 50 \pm 0.05\end{array}$ & $\begin{array}{l}\mathrm{N}=66 \\
\mathrm{Age}=28 \cdot 8 \pm 8 \cdot 2 \\
\mathrm{RCD}=0.49 \pm 0.06\end{array}$ \\
\hline
\end{tabular}

\section{CORRELATION WITH OTHER BLOOD}

VARIABLES

Within the same population as above, it was found that there were no significant correlations between $\mathrm{RCD}$ and plasma viscosity $(r=0.05)$, low shear blood viscosity $(r=0 \cdot 017)$, fibrinogen $(r=0 \cdot 10)$, or the white cell count $(r=0 \cdot 17)$.

\section{EFFECT OF SEX AND SMOKING}

A group of 60 normals less than 50 years old were subdivided for sex and smoking habit as shown in the Table. No significant difference was found between males and females, or between smokers and non-smokers $(\mathrm{P}>0.05)$.

\section{RELATION TO VASCULAR DISEASE}

Thirty men admitted to hospital suffering from acute myocardial infarction or intermittent claudication were studied and compared with a group of agematched controls. Figure 3 shows that these patients

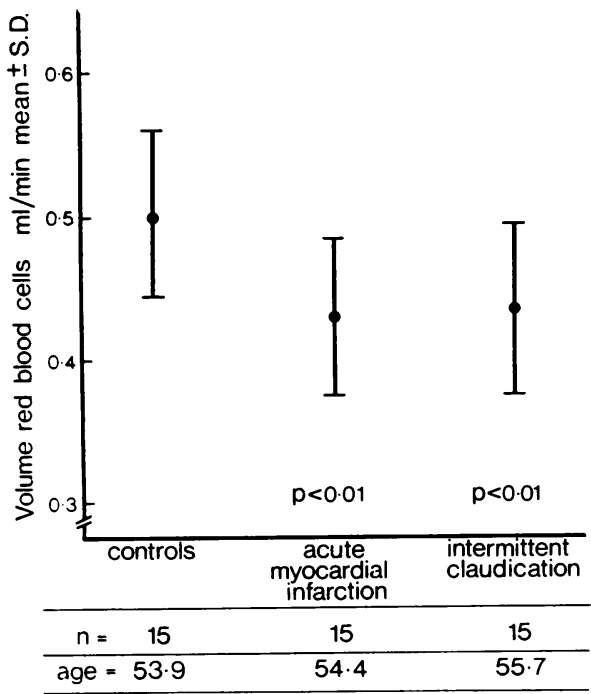

Fig. 3 Red cell deformability in myocardial infarction and intermittent claudication. suffering from acute and chronic vascular disease had significantly more 'rigid' cells $(P<0.01)$ than the control group.

\section{Discussion}

We have found the filtration method of Reid et al. ${ }^{1}$ to be a reproducible and relatively simple means of estimating red cell deformability, allowing large numbers of patients to be studied. We have confirmed that the time taken for whole blood to filter is strongly dependent on the haematocrit, and that simple multiplication of the volume of blood filtered per minute by the haematocrit abolishes this correlation. We investigated the validity of the method as a measure of deformability in two ways. Firstly, fixation of red cells by glutaraldehyde produced a marked fall in the deformability index, as shown previously by Schmid-Schönbein et al. ${ }^{6}$ Secondly, the deformability index correlated with blood viscosity measured at a high shear rate. Schmid-Schönbein et $a l^{7}$ and $\mathrm{Chien}^{8}$ have shown that blood viscosity falls at high shear rates, due to increased deformation of red cells. Our findings, therefore, suggest that results using the method of Reid et al. ${ }^{1}$ are indeed related to red cell deformation.

We found no correlation between red cell deformability and plasma fibrinogen, or between red cell deformability and blood viscosity at low shear rates. It is, therefore, unlikely that the filtration method measures red cell aggregation. Neither did we find a correlation between red cell deformability and plasma viscosity, or between red cell deformability and the white cell count up to $15 \times 10^{9} / 1$. We therefore doubt whether plasma viscosity effects, or blockage of pores by white cells, have major effects on red cell deformability values. These findings suggest that it is valid to measure filtration rates of whole blood samples without removal of white cells or resuspension of red cells in solutions other than plasma. However, the method may not be applicable to samples with very high white cell 
counts (leukaemia) or very high plasma viscosity (macroglobulinaemia or myeloma). We found no relation of red cell deformability to sex or to smoking habit.

It has been suggested that red cells which have impaired deformability may impair blood flow in the microcirculation, the cells being less able to squeeze through capillaries. ${ }^{7}$ It is therefore of interest to study red cell deformability in patients with vascular disease. Our finding that patients with chronic peripheral arterial disease had less deformable cells agrees with the study of Reid et al. ${ }^{9}$ We have also shown that men with acute myocardial infarction have fewer deformable cells. It therefore appears that the method described by Reid et al. ${ }^{1}$ will be useful in the study of red cell deformability in vascular disease.

\section{References}

1 Reid HL, Barnes AJ, Lock PJ, Dormandy JA, Dormandy TL. A simple method for measuring erythrocyte deformability. $J$ Clin Path 1976;29:855-8.

${ }^{2}$ Rampling M, Sirs JA. The interactions of fibrinogen and dextrans with erythrocytes. J Physiol 1972;223: 199-212.
${ }^{3}$ Weaver JPA, Evans A, Walder DN. The effect of increased fibrinogen content on the viscosity of blood. Clin Science 1969;36:1-10.

${ }^{4}$ Clauss A. Gerinnungsphysiologische Schnellmethode zur Bestimmung des Fibrinogens. Acta Haematol 1957;17:237-46.

${ }^{5}$ Largo R, Heller V, Straub PW. Detection of soluble intermediates of the fibrinogen-fibrin conversion using erythrocytes coated with fibrin monomers. Blood 1976;47:991-1002.

${ }^{6}$ Schmid-Schönbein H, Weiss J, Ludwig H. A simple method for measuring red cell deformability in models of the microcirculation. Blut 1973;26:369-79.

${ }^{7}$ Schmid-Schönbein H, Wells R, Goldstone J. Influence of deformability of human red cells upon blood viscosity. Circulat Res 1969;25:131-43.

${ }^{8}$ Chien S. Blood rheology and its relation to flow resistance and transcapillary exchange with special reference to shock. Adv Microcirc 1969;2:89-103.

${ }^{9}$ Reid HL, Dormandy JA, Barnes AJ, Lock PJ, Dormandy TL. Impaired red cell deformability in peripheral vascular disease. Lancet 1976;1 :666-8.

Requests for reprints to: Dr MM Drummond, University Department of Medicine, Royal Infirmary, Glasgow G4 OSF, UK. 